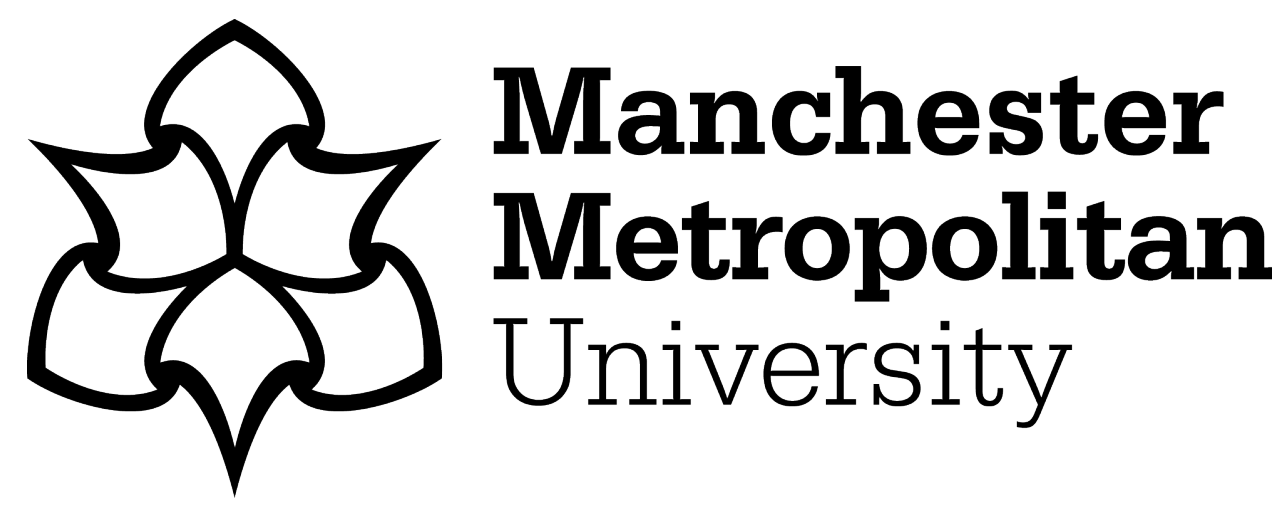

Fan, Y and Stevenson, M (2018) A review of supply chain risk management: definition, theory, and research agenda. International Journal of Physical Distribution and Logistics Management, 48 (3). pp. 205-230. ISSN 09600035

Downloaded from: https://e-space.mmu.ac.uk/621434/

Version: Accepted Version

Publisher: Emerald

DOI: https://doi.org/10.1108//JPDLM-01-2017-0043

Please cite the published version 


\section{A Review of Supply Chain Risk Management: Definition, Theory, and Research Agenda}

\begin{tabular}{|r|l|}
\hline Journal: & International Journal of Physical Distribution \& Logistics Management \\
\hline Manuscript ID & IJPDLM-01-2017-0043.R3 \\
\hline Manuscript Type: & Research Paper \\
\hline Keywords: & $\begin{array}{l}\text { Supply chain risk, Risk management, Supply chain risk management } \\
\text { (SCRM), Systematic literature review (SLR), Theory }\end{array}$ \\
\hline \multicolumn{2}{|l}{} \\
\hline
\end{tabular}

SCHOLARONE $^{\text {tw }}$

Manuscripts 


\title{
A Review of Supply Chain Risk Management: Definition, Theory, and Research Agenda
}

\begin{abstract}
Purpose: To review the extant literature on supply chain risk management (SCRM, including risk identification, assessment, treatment, and monitoring), developing a comprehensive definition and conceptual framework; to evaluate prior theory use; and to identify future research directions.

Design/methodology/approach: A systematic literature review of 354 articles (published 2000-2016) based on descriptive, thematic, and content analysis.

Findings: There has been a considerable focus on identifying risk types and proposing risk mitigation strategies. Research has emphasised organisational responses to supply chain risks and made only limited use of theory. Ten key future research directions are identified.

Research implications: A broad, contemporary understanding of SCRM is provided; and a new, comprehensive definition is presented covering the process, pathway, and objectives of SCRM, leading to a conceptual framework. The research agenda guides future work towards maturation of the discipline.
\end{abstract}

Practical implications: Managers are encouraged to adopt a holistic approach to SCRM. Guidance is provided on how to select appropriate risk treatment actions according to the probability and impact of a risk.

Originality/value: The first review to consider theory use in SCRM research and to use four SCRM stages to structure the review.

Keywords: Supply chain risk, Supply chain risk management (SCRM), Risk management, Systematic literature review (SLR), Theory

Paper type: Literature review 


\section{Introduction}

Various industrial trends, including outsourcing, supply base reduction, just-in-time, and shorter product life cycles have increased firm exposure to supply chain risks (SCRs) (Colicchia and Strozzi, 2012; Trkman et al., 2016). These risks may result from man-made problems or natural disasters, and can have major consequences for organisations, including financial and operational problems, potentially leading to business discontinuity (Craighead et al., 2007; Rajesh et al., 2015). Within the SCR literature, supply chain risk management (SCRM) has become a key area of interest. SCRM is aimed at developing strategies for the identification, assessment, treatment, and monitoring of risks in supply chains (e.g. Neiger et al., 2009; Tummala and Schoenherr, 2011; Ho et al., 2015), yet several gaps in knowledge exist. From a conceptual perspective, researchers are yet to agree on a definition of SCRM, with the literature stressing its multifaceted and complex nature (Sodhi et al., 2012; Ho et al., 2015). From a theoretical perspective, it is unclear how theories have been used in the extant literature to further our understanding of SCRM. And from an integrative perspective, knowledge gathered along narrow functional disciplines (such as purchasing and logistics) needs to be consolidated to advance SCRM research and create a coherent knowledge framework.

We contend that in order to develop a better understanding of the above-mentioned issues, a systematic review of the current state-of-the-art is needed. While there have been several recent reviews, these have only partially addressed conceptual issues and have not systematically examined how theory has been used. For example, there have been 15 'traditional' (non-systematic) literature reviews in the last decade (e.g. Tang and Musa, 2011; Ho et al., 2015). While valuable, these studies have either been based on a limited number of articles, e.g. 55 articles in Rao and Goldsby (2009) and 138 articles in Tang and Musa (2011), or have had a specific focus, e.g. on quantitative models (e.g. Tang, 2006; Heckmann et al., 2015) or a particular industry (e.g. Aloini et al., 2012; Boyson, 2014). An exception is the review of SCRM research between 2003 and 2013 by Ho et al. (2015). But the SCRM field is so rapidly growing that 138 papers have been published since 2013 . There have also been five systematic literature reviews (SLRs) - a type of structured approach to conducting a literature review (Denyer and Tranfield, 2009; Saenz and Koufteros, 2015) - on SCR. Yet similar observations regarding size and scope apply to these SLRs, which have either been based on a limited number of articles, e.g. 55 articles in Colicchia and Strozzi (2012) and 86 articles in Kilubi (2016), or had a narrow focus, e.g. on price risk (Fischl et al., 2014) or quantitative models (Fahimnia et al., 2015). Again, 
none of these reviews have given particular attention to theory. It is therefore argued that a new SLR on SCRM is needed. The objectives of this review are to:

1. Provide a comprehensive definition of SCRM;

2. Present a state-of-the-art assessment of SCRM research across four SCRM stages (i.e. risk identification, assessment, treatment, and monitoring); and,

3. Assess the use of theory in SCRM research.

The remainder of this paper is organised as follows. The SLR approach is first outlined followed by the development of a new, comprehensive definition of SCRM and a conceptual framework. General descriptive statistics are then presented before the extant literature is classified and analysed according to the four SCRM stages. Theory use is then assessed before future research directions are identified; finally, conclusions are provided.

\section{Methodology}

A seven-stage systematic literature review process has been followed, as illustrated in Figure 1 and described below.

\section{[Take in Figure 1]}

\section{Stage 1 - Question Formulation}

This review seeks to address the research questions included in Figure 1. The questions guide the review, defining which studies to include and what data to extract (Denyer and Tranfield, 2009). As suggested by Tranfield et al. (2003), multiple researchers have been involved to reduce subjective bias.

\section{Stage 2 - Keyword Search}

Two search engines were used: Business Source Complete (EBSCO host) and Web of Science. These two databases provide arguably the best coverage of operations and SCM, and they are commonly used in literature reviews. The search terms 'supply chain' AND 'risk' were used, as adopted by Ho et al. (2015), for the title, abstract, keywords, and thereafter main text. We have adopted a unionist perspective (Larson and Halldorsson, 2004) whereby 'logistics' is considered part of SCM. Therefore, the term 'supply chain' was used for our search instead of 'logistics'. Logistics risk is considered to be one type of SCR; similarly, we did not search individually for quality risk, price risk, etc. These broad terms ensured papers adopting alternative nomenclature were identified. As a first proxy for quality, only international scholarly peer-reviewed articles were selected. Further, the 
search was limited to articles published 2000-2016 to provide a contemporary perspective on the phenomenon. This returned 5,412 articles.

\section{Stage 3 - Removing Duplicates}

After removal of duplicates, the number of articles was reduced to 4,150 papers.

\section{Stage 4-Article Quality and Relevance}

As a second proxy for quality, articles published in journals not included in the 2015 ABS list were eliminated. This approach was also adopted by Ghadge et al. (2012) using an earlier version of the list. Irrelevant studies, including on accounting and economics, and less relevant papers on topics other than SCRM, including those focused on supplier selection and outsourcing, were also removed. The retained papers mainly included a focus on at least one SCRM stage. To ensure the spotlight remained on SCRM, articles that focused on related concepts, such as uncertainty, disruption, and resilience were only retained if they explicitly employed SCRM practices. Overall, this reduced the database to 345 papers.

\section{Stage 5 - Capturing Other Relevant Articles}

To identify other relevant work that had not been captured, the references of the 345 papers were checked, resulting in a further 5 articles. An additional search for completeness was conducted in Google Scholar but retrieved only a further 4 articles, thereby confirming the previous steps were appropriate. Thus, the final database contains 354 articles.

\section{Stage 6-Full-text Analysis and Coding}

In addition to basic bibliographic information (e.g. author(s), year, and journal), the 354 papers were coded in NVivo according to: country context; industry sector; theory; type of theory use; research perspective; research method; and SCRM (including risk identification, assessment, treatment, and monitoring). As an example, research perspective was broken down into four sub-codes: supplier's perspective, buyer's perspective, dyadic perspective, and triadic perspective. Some of the analysis was clearly deductive (e.g. categorisation according to developed vs. developing country), while others (e.g. enablers of risk mitigation strategies and evaluation of strategies) were more inductive (i.e. emerging from the papers). Multiple researchers were involved in determining and validating the final set of codes. 
Stage 7 - Reporting

After SCRM has been defined below, the general descriptive and thematic analysis are reported, respectively.

\section{Defining SCRM and Proposing a Conceptual Framework}

Existing definitions of SCRM, summarised in Table I, can be divided into three categories of characteristics.

\section{[Take in Table I]}

\section{SCRM Process}

It has been suggested that risk identification, risk assessment, risk treatment, and risk monitoring represent the four main stages of the SCRM process (Zsidisin et al., 2005; Hachicha and Elmsalmi, 2014). This is in accordance with the main stages defined in ISO 31000 (2009), an alternative approach. These four stages have been used to classify the definitions of SCRM in Table I.

\section{Pathway to SCRM}

Several definitions highlight the importance of selecting and implementing appropriate SCRM strategies (Faisal et al., 2007; Manuj and Mentzer, 2008b). This is broadly referred to as the pathway to SCRM; and includes external coordination and collaboration among supply chain partners, and the internal implementation of SCRM strategies.

\section{Objective of SCRM}

Several definitions refer to the objective(s) of SCRM (e.g. Wieland and Wallenburg, 2012). For example, from a financial perspective, SCRM involves cash-flow management to ensure profitability (e.g. Faisal et al., 2007) and to save costs (Manuj and Mentzer, 2008b). From a business continuity perspective, SCRM manages exposure to serious business disruptions arising from risk within and outside the supply chain. In this sense, SCRM aims to build the capability to reduce vulnerability and ensure business continuity (Jüttner, 2005; Goh et al., 2007; Wieland and Wallenburg, 2012). When a firm is better able to manage risks than the competition, it can lead to an improved market position. Thus, SCRM aims not only to reduce costs and vulnerability but also to ensure profitability, business continuity, and potentially longer-term growth.

\section{A New Definition of SCRM}

SCRM is a multi-faceted concept. As a result, different researchers have defined SCRM in 
different ways. Some emphasise the pathway and objectives of SCRM but do not pay explicit attention to the SCRM stages (Norrman and Jansson, 2004; Tang, 2006). Ho et al. (2015) and Wieland and Wallenburg (2012) meanwhile took a holistic view, incorporating the four stages of SCRM, but they omitted either the objectives or the pathway to SCRM. Others have only included a subset of the SCRM process; for example, Lavastre et al. (2012) highlighted risk assessment in particular but ignored the characteristics of the pathway to SCRM and the objectives of SCRM.

The above calls for a new, comprehensive definition that is: (i) internally consistent, so SCRM can reflect both the nature of risk management and SCM, providing researchers from different fields with a common understanding of SCRM; and, (ii) externally consistent, so researchers can guide their work towards solving real business problems. Our definition is therefore:

The identification, assessment, treatment, and monitoring of supply chain risks, with the aid of the internal implementation of tools, techniques and strategies and of external coordination and collaboration with supply chain members so as to reduce vulnerability and ensure continuity coupled with profitability, leading to competitive advantage.

This definition reflects the full SCRM process, the pathway to SCRM, and the objectives of SCRM. It is a holistic definition that denotes the positive outcome of managing negative forms of SCR, eventually resulting in competitive advantage, and it offers a conceptualisation embedded in Figure 2 that integrates Objectives-based, Processbased, and Outcome-based thinking into one (OPO-based) framework. The conceptual framework helps understand the objectives of SCRM that motivate a firm to select and implement strategies in the SCRM process while also investigating how internal and external pathways influence SCRM practices and their outcomes from a holistic viewpoint.

[Take in Figure 2]

\section{Descriptive Analysis}

General Trends in the Literature

Figure 3 illustrates the number of articles (out of 354) published on SCRM annually since 2000. It shows the high growth rate of the field, with the number of papers increasing yearon-year since 2005, with the exception of 2010 and 2015. Only 8\% of articles were 
published 2000-2005; 24\% were published 2006-2010; and 68\% were published 2011-2016. As shown in Figure 4, 51\% of articles were published in 9 key journals, including the International Journal of Physical Distribution \& Logistics Management, with the other (approximately) half scattered across 60 journals, e.g. Decision Sciences and Management Science.

\section{[Take in Figure 3 and Figure 4]}

\section{Country \& Industry Sector}

Among the 354 papers, 124 referred to the country context (either a single country or multiple countries), as shown in Table II. Most work is conducted in a single country (106 of 124). Further, most work is in a developed country context (69 papers), such as the UK (e.g. Johnson et al., 2013; Roehrich et al., 2014) or USA (e.g. Ellis et al., 2010), with 48 papers focused purely on a developing country context.

\section{[Take in Table II]}

Many studies focused on a specific industry (115 papers) or industries (70 papers), as shown in Table II. The most studied sectors are automotive (e.g. Blackhurst et al., 2008; Ceryno et al., 2015), manufacturing (e.g. Schoenherr et al., 2008; Ellinger et al., 2015), and food (e.g. Jensen et al., 2015). The nature of the risks and most suitable management practices may differ across countries and industries; hence, there is scope to further our understanding of SCRM by considering other contexts.

\section{Research Perspective}

Table II also summarises the research perspective adopted (for 115 out of 354 papers). The most dominant approach has been to adopt a buyer perspective ( 88 papers). Only 5 papers were from the supplier's perspective (e.g. Ojala and Hallikas, 2006). Studies from a dyadic or triadic perspective are also few (e.g. Simangunsong et al., 2016), which may reflect the difficulty of data collection across multiple actors in the same network. More studies from a supplier perspective or that obtain multiple perspectives would help further our understanding of SCRM.

\section{Research Method}

As shown in Table III, 99\% of papers have employed one research method in a single paper while $1 \%$ presented a mixed methods approach. Among single research method papers, 167 papers are based on empirical data, mainly the (single or multiple) case study (103 papers) or survey method (55 papers). In addition, 63 conceptual studies and 113 analytical studies 
based on quantitative analysis were found. The use of secondary data has been limited, with only 7 papers included. There is scope to use a broader range of research methods, including innovative approaches, to further our understanding of SCRM.

\section{[Take in Table III]}

\section{Thematic Analysis: The SCRM Process}

In total, 339 (out of 354) papers on SCRM explicitly refer to at least one SCRM stage, while the remainder contribute to our general understanding of SCRM (e.g. Sodhi et al., 2012). According to Table IV, most papers have focused on a single stage, developing a narrow but deep understanding. The majority focus has been on risk treatment, and particularly on risk mitigation approaches to treating risk, while least attention has been on risk monitoring. Only 6 papers (Norrman and Jansson, 2004; Sinha et al., 2004; Zsidisin et al., 2005; Manuj and Mentzer, 2008a; Tummala and Schoenherr, 2011; Lavastre et al., 2012) considered all four stages (i.e. a holistic approach). Where papers cover two (or three) stages, most work has logically focused on consecutive stages (e.g. Tsai et al., 2008; Chang et al., 2015), except some (40 out of 339 papers) that 'jump' from risk identification to risk treatment without substantial coverage of risk assessment (e.g. Ceryno et al., 2015).

\section{[Take in Table IV]}

\section{Risk Identification}

Risk identification aims to discover all relevant risks (Kern et al., 2012) and recognise future uncertainties to manage them proactively. This stage is critical to the success of managing SCRs (Neiger et al., 2009) - only by identifying a risk can any risk management activity be triggered. This implies an early judgement is needed in risk identification to decide whether a risk is relevant and thus should be further assessed or mitigated (Enyinda et al., 2010). Hence, risk identification needs to follow a comprehensive approach to identifying all potential supply chain threats and vulnerabilities (Kern et al., 2012).

\section{Drivers of SCR}

Drivers of SCRs include probability and impact drivers. Probability drivers are competitive pressures with risk-source implications (Ritchie and Brindley, 2007) that might increase or decrease supply chain vulnerability (Wagner and Bode, 2006). For example, a focus on efficiency by applying lean approaches can make a supply chain vulnerable (Thun and Hoenig, 2011). Impact drivers are conditions with risk-consequence implications (Sinha et al., 2004; Wagner and Bode, 2006) that affect the magnitude of loss (e.g. standardised 
contracts and supplier dependence). Some risk drivers, including withholding information (Sinha et al., 2004), partnerships, and other close relationships (Li et al., 2015; Chen et al., 2016), can be both probability and impact drivers. By understanding these drivers, not only can SCRs be identified but, more crucially, risk treatment plans can be designed that remove both probability and impact drivers.

Types of SCR

Approximately $26 \%$ of the articles (91 out of 354) have included a focus on risk identification. Disagreements over how to classify risks are influenced by the fact that most empirical research is context-specific and the data are collected from diverse industries and countries. There are studies that produce extensive lists of risk types (18 papers) but without further classification of the risks (e.g. Olson and Wu, 2011; Lavastre et al., 2014). There are others that suggest classification schemes (20 papers) but without identifying the specific risks in each category (e.g. Matook et al., 2009). And there are studies (53 papers) that integrate the two, listing the potential risks in each category (e.g. Faisal et al., 2007; Christopher et al., 2011; Rangel et al., 2015). This indicates that most scholars have been aware of two phases of risk identification, i.e. risk listing and categorising; however, research has failed to identify inter-relationships between risks and risk categories.

\section{SCR Identification Strategies}

There are many approaches in the literature for identifying risks. Some have been proposed by researchers but not yet applied; some have been proposed and applied by researchers; and there are some with evidence of use in practice by companies. Whereas research has focused on relatively complex approaches to risk identification, e.g. via the analytical hierarchy process (AHP) (Gaudenzi and Borghesi, 2006) and the value-focused process engineering (VFPE) methodology (Neiger et al., 2009), practitioners appear more focused on simple and established methods (e.g. the Ishikawa diagram and value stream mapping). Kayis and Karningsih (2012) developed and applied a risk identification tool known as the supply chain risk identification system (SCRIS), but there is no evidence of this being routinely applied by practitioners themselves. The cause-effect diagram appears to be the only technique applied by both researchers (Lin and Zhou, 2011) and practitioners (Lavastre et al., 2012). It remains to be seen how some of the methods proposed by researchers perform in practice (e.g. versus simpler approaches) and whether they would be independently applied by practitioners. It may therefore be important to find a way of bridging the gap between the methods advocated by research and routinely adopted in 
practice.

\section{Risk Assessment}

Effective SCRM requires a comprehensive yet rapid and cost-efficient assessment (Zsidisin et al., 2004) of SCRs. Risk can be assessed using data (if available) or expert judgement and scenarios (Cohen and Kunreuther, 2007). This means risk assessment can be formal or informal and quantitative or qualitative (Zsidisin et al., 2004). Gaudenzi and Borghesi (2006) argued risk assessment is inherently subjective as each analyst has his/her own concept of what constitutes a risk and of the nature of upstream/downstream relationships. Tsai et al. (2008) concluded that combining objective data and subjective perception might result in a more robust construction of risks, which in turn would improve the effectiveness of risk prediction and assessment. In assessing risk, the following factors should be considered.

\section{SCR Prioritisation}

Risk prioritisation helps organisations identify the most significant risks. High priority might be given to risks that have a high degree of impact or that can be mitigated immediately (Sinha et al., 2004). Developing and implementing risk treatment actions involves considerable investment, and it is unlikely that a company will be able to deal with all possible risks. Risk prioritisation therefore helps decide which risk types to develop actions against, allowing a firm to manage its limited risk treatment resources (Zsidisin et al., 2004). So far, researchers have attempted to prioritise risks mainly in the process of uncovering risk inter-relationships (e.g. Hachicha and Elmsalmi, 2014; Govindan and Chaudhuri, 2016) or by applying risk assessment tools, such as failure modes and effects analysis (FEEA) (e.g. Bradley, 2014) and the analytic hierarchy process (AHP) (e.g. Mu and Carroll, 2016).

SCR Inter-relationships

A risk event is rarely an isolated incident; there are often inter-relationships with other risks and the impact of risks can be felt across the supply chain (Kayis and Karningsih, 2012). Understanding knock-on effects and inter-relationships helps with risk prioritisation, assessing the criticality of supply risks (Guertler and Spinler, 2015), creating risk treatment plans (Chopra and Sodhi, 2004), and implementing effective risk management activities (Sarker et al., 2016). Yet few studies (e.g. Hachicha and Elmsalmi, 2014; Venkatesh et al., 2015) have applied structural modelling tools to identify risk inter-relationships. Hachicha 
and Elmsalmi (2014) and Venkatesh et al. (2015) did however apply interpretive structural modelling (ISM) and MICMAC (Matriced Impacts Cruoses Multiplication Applique a un Classement) analysis in the food and apparel industries, respectively to show the interrelationships between risk sources and variables. The central idea is to determine the most critical risk that may give rise to multiple risks, resulting in a domino effect (Venkatesh et al., 2015). Sarker et al. (2016) further uncovered and classified different types of dependences amongst various risks into positive dependence (i.e. where removing one risk helps mitigate one or several risks) and negative dependence (i.e. where removing one risk may create one or several other risks). Further empirical research is needed to reveal more complex inter-relationships as removing one risk might help mitigate certain risks whilst simultaneously creating others.

\section{SCR Assessment Strategies}

Out of the 354 papers, 76 advocated, implemented or reported on an industrial application of a risk assessment strategy. Much of this work has focused on formalised tools for SCR assessment, such as bayesian belief networks (BBN) (Nepal and Yadav, 2015). But the most popular method applied by both researchers and companies is the probability-impact (P-I) risk matrix. This was advocated by, e.g. Blackhurst et al. (2008), applied in practice through research by, e.g. Chang et al. (2015), and used by Marks \& Spencer (Khan et al., 2008).

Although many studies have discussed risk assessment strategies, there are still areas in need of further study. First, assessments of risk should take into account intangible, nonregulated consequences and losses. For instance, credibility, reputation, status, authority, and trust can be damaged if a risk is realised (Roehrich et al., 2014). These immaterial consequences are often overlooked by researchers. Second, managers often assess probability based on their own experience and companies' performance, but it is important to consider how other indicators or signals of change in the business environment can be incorporated (Hora and Klassen, 2013). Third, a broader supply chain understanding of risk is needed; for example, not only do direct risks need to be assessed, the potential causes or sources of those risks also need to be examined at every significant link along the chain (Wever et al., 2012).

\section{Risk Treatment}

The literature adopts various terms for the types of risk treatment actions available, influenced by the business context under study (e.g. Diabat et al., 2012; Lavastre et al., 
2014). In the following, five generic risk treatment types are outlined: risk acceptance, avoidance, transfer, sharing, and mitigation. The majority of research has focused on risk mitigation.

\section{Risk Acceptance}

There are no standard guidelines to determine how much risk an organisation should accept. The acceptable level is context-dependent and may be linked, for example, to risk propensity, i.e. the willingness of a person or organisation to engage in risky behaviours and accept uncertain outcomes in decision-making (Park et al., 2016). But willingness to accept a risk does not mean the risk has to be ignored. It should continue to be tracked to ensure the accepted consequences do not escalate (Aqlan and Lam, 2015). If the consequences exceed a certain threshold, organisations need to consider how to avoid, transfer, share, or mitigate the risk.

Risk Avoidance

Risk avoidance seeks to eliminate the types of events that could trigger a risk (Ritchie and Brindley, 2007). For example, a company could discontinue specific products, suppliers, or geographical markets if supply is unreliable (Jüttner et al., 2003; Hajmohammad and Vachon, 2016). Thus, the company is removing the root cause of the risk (Aqlan and Lam, 2015).

\section{Risk Transfer}

Risk transfer indicates that responsibility is assigned to another party (Diabat et al., 2012). For example, business disruption risks can be transferred through business interruption insurance (Zhen et al., 2016). Risk transfer however appears more appropriate for disruption risks with a small probability and high impact, e.g. natural disasters and terrorist attacks, than for operational risks with a high probability and low impact (Aqlan and Lam, 2015).

\section{Risk Sharing}

Risk sharing involves another party sharing some or all risks. From the buyer's perspective, risk can be shared usually through contracts with clauses that account for potential changes in associated risks (Buzacott and Peng, 2012) and relationship development (Camuffo et al., 2007). Suppliers, for example, would pre-order to share inventory risk in the presence of financial constraints (Lai et al., 2009) or increase capacity when orders are guaranteed by their customers (Scheller-Wolf and Tayur, 2009). Similar to risk transfer, risk sharing 
seems appropriate for dealing with risks that have a low probability and high impact in order to reduce the associated costs (Lai et al., 2009) and increase customer service levels (Scheller-Wolf and Tayur, 2009).

\section{Risk Mitigation}

Mitigation seeks to actively reduce risk to an acceptable level. It applies both to the reduction of the probability of a risk event and to the consequences (Norrman and Jansson, 2004). Mitigation strategies are typically suitable for operational risks with a high probability and low impact (Aqlan and Lam, 2015). The selection of a risk mitigation strategy also depends on the risk type and the organisation's budget (Tummala and Schoenherr, 2011); and organisations should carefully evaluate the acceptance, avoidance, sharing, and transfer options before selecting a mitigation strategy. As risks are often interconnected, alleviating one risk type might aggravate and/or mitigate another (positive vs. negative dependence); hence, mitigation strategies should be employed with minimal contradiction (Chopra and Sodhi, 2004) and with particular attention to those risks that have negative dependences (Sarker et al., 2016).

Different clusters of risks may need different risk treatment strategies, as illustrated in Figure 5. As a firm has limited resources, it is important to understand where these resources can be best deployed and when to change outdated strategies. Investing in risk avoidance seems necessary for high probability, high impact risks to reduce their likelihood of occurrence, whereas risk acceptance may be permitted for low probability, low impact risks. Risk mitigation appears most suitable for high probability, low impact risks while risk transfer/sharing seems most appropriate for disruption risks with a low probability and high impact, such as natural disasters and terrorist attacks. But the situation needs to be continually monitored - the theme of the next section - for each risk and across risks to capture the evolution of the strategies and ensure the strategies remain aligned with the threats.

\section{[Take in Figure 5]}

\section{Risk Monitoring}

Risk is not a static phenomenon. It needs to be continuously monitored to evaluate how risk sources are developing and if any changes to the treatment strategies need to be applied. It is important to ensure that risk monitoring is based not only on judgemental assessments but also on formal processes, e.g. so the on-going progress of SCRM is continuously 
updated and reviewed, so changes are managed, and so new information is obtained (Zsidisin, 2003). Although risk monitoring is an important part of SCRM, it has received limited attention (Blackhurst et al., 2008; Hoffmann et al., 2013). Only ten papers (out of 354) paid explicit attention to monitoring. There is a need for further research at this stage, particularly given the differences in opinions between researchers and practitioners. Researchers have suggested establishing specific data management systems for risk monitoring (Tummala and Schoenherr, 2011), developing monitoring capabilities (Klassen and Vereecke, 2012) and early-warning management processes (Xie et al., 2009), and designing tools (Blackhurst et al., 2008) to identify trends. In contrast, managers tend to incorporate monitoring tasks into existing management routines, such as by combining monitoring with risk assessment (Blackhurst et al., 2008) and by monitoring through key performance indicators (KPIs) (Lavastre et al., 2012) and performance measurement systems (Bühler et al., 2016).

\section{Assessment of the SCRM Process}

The four SCRM stages have received differing degrees of attention. For example, there has been more research on risk identification and treatment than on risk assessment and monitoring. The literature has provided various tools and strategies that can be used during each stage, but few studies have examined their effectiveness or provided managerial guidance on when and how to select them. Moreover, there appear to be differences in terms of the strategies advocated by researchers and those typically employed in practice.

In terms of the pathway to SCRM, coordination and collaboration with other members of the supply chain is important. As part of this, relational aspects, and not simply contracts, are key. Contractual mechanisms can be important to developing effective risk management between firms (Ojala and Hallikas, 2006), but it has even been argued that long term relationships may be efficient without contracts in some cases (Cohen and Kunreuther, 2007). Indeed, a few studies have highlighted how effective relationships can help manage potential SCRs (e.g. Cruz and Liu, 2011; Chen et al., 2016). But further work is needed to disentangle the dynamic interplay between contractual mechanisms and relational mechanisms; and to give greater attention to relational mechanisms (including in dyadic and triadic relationships) during the SCRM process.

Implementing a SCRM strategy involves an investment as well as potential benefits. Although some studies have attempted to examine the effect of SCRM activities on supply chain performance (Thun and Hoenig, 2011) or risk performance (Kern et al., 2012), there 
is limited research on the operationalisation of supply chain performance measures and of the associated moderators and mediators in relation to SCRM. For example, factors such as national culture (Jia and Rutherford, 2010), buyer's perceptions (Ellis et al., 2010), and the decision-making process (Ellis et al., 2011) could influence SCRM and its effect on performance.

\section{Thematic Analysis: Theories in SCRM Research}

This section focuses on the use of theory in SCRM research, which has been neglected in previous reviews. For the subset of articles that have used theory, this review has determined: whether a single or multiple theories were used; which theories were used; and, the number of key constructs included from each theory. The extent, or degree, of theory use was coded along a continuum from informed by theory to building theory, as below. These points on the continuum were informed by Painter et al. (2008) and further developed based on the authors' preliminary analysis:

- Informed by theory: Where a theoretical framework or construct is identified but there is no or limited application of the framework in the study's components and measures.

- Applying theory: Where a theoretical framework is specified and between one and all constructs is/are applied in components of the study.

- Testing theory: Where a theoretical framework is specified and some or all of the theoretical constructs are measured and explicitly tested.

- Building theory: Where new or revised/expanded theory is developed using constructs specified, measured, and analysed in the study.

Table $\mathrm{V}$ summarises the trend in using theory, demonstrating a gradual broadening out of the range of theories used. In total, only 45 papers utilised theory, with most adopting a single lens (e.g. Yang and Yang, 2010; Hoffmann et al., 2013). Most studies imported theory from other fields, with Transaction Cost Economics (TCE) the most commonly employed theory frame. Nine papers used multiple theories (e.g. Ellis et al., 2010; Speier et al., 2011); most notably, TCE with the Resource-Based View (RBV) (Ojala and Hallikas, 2006; Tsai et al., 2008). Therefore, theory is used on 53 occasions across the 45 papers. Details of each type of theory use are explained below, using examples from the papers.

[Take in Table V] 
Informed by Theory

Many of the SCRM contributions that make some use of theory fall towards this end of the continuum (20 out of 53 theory uses). This suggests many researchers provide limited insight into how theories were operationalised in measurement, analysis, and/or the design of SCRM research; or there is reference to a theory but the empirical data is presented with no or little connection to the theory. For example, Hallikas et al. (2002) mentioned TCE, but there was little evidence of it adding explanatory power to the research topic (i.e. risk analysis and assessment). More specifically, it does not appear as though removing explanation of the theory from the paper would greatly affect the research findings. Other examples have drawn upon established theories to develop propositions (Blome and Schoenherr, 2011), propose other arguments (e.g. Guertler and Spinler, 2015) or provide background information (e.g. Cantor et al., 2014), but none of the theoretical constructs were explicitly discussed.

Arguably, research at this end of the continuum is not taking full advantage of theory potential. Being informed by theory however is still valuable and can influence the way in which SCR is conceptualised. For example, systems theory has been used to inform understanding of risk, where risk has been understood as the links tying open systems together into large and interconnected networks of systems (Peck, 2005), indicating risks are inherently inter-related (Guertler and Spinler, 2015). Without this theory, such studies would have been more likely to ignore risk inter-relationships.

\section{Applying Theory}

Research of this kind has applied theory to increase research rigour or add explanatory power to research findings (25 out of 53). A good example is Johnson et al. (2013) who, based on a single case study, used all of the key constructs of social capital theory to provide new insight into formative capabilities for supply chain resilience.

\section{Testing Theory}

In this category, a theoretical framework is specified and some or all of the constructs are measured and explicitly tested (7 out of 53). For example, Camuffo et al. (2007) applied agency theory to study risk sharing between buyers and first-tier suppliers and develop hypotheses. Similarly, Ellinger et al. (2015) used the Knowledge Based View (KBV) to develop a conceptual framework and hypotheses to understand that learning orientation is a cultural factor that favourably influences SCRM. Further, survey data was used to test the hypotheses in the conceptual framework. Such employment of theory demonstrates 
consistency between the theory itself and the research findings.

\section{Building Theory}

Only one paper was classified as theory building. Wever et al. (2012) expanded TCE from a focus on bilateral transactions to examine transactions by taking a supply chain-wide approach to reduce transaction risk exposure. This research reshaped our understanding of managerial practices derived from traditional TCE and justified why a supply chain-wide perspective is needed in managing transaction risks, thereby reducing imbalances between supply- and demand-side contracts.

\section{Assessment of Theory Use}

Although only a limited number of papers have used theory in the SCRM literature, there is evidence of a broad range of different theories being adopted. Not all of these theory applications have added greatly to understanding of SCRM, although this does not mean the papers did not provide a valuable contribution. Further analysis revealed that the papers using theory tended to focus on a particular stage or subset of stages in the SCRM process. Overall, no theoretical perspective has captured the full SCRM process, and thus it remains to be seen whether a holistic approach to SCRM would require the use of multiple theory frames.

\section{Discussion: Gaps in SCRM Research}

Ten key research gaps are identified, as summarised in Table VI, together with proposed potential research questions. These gaps and questions represent an agenda for future research and are derived from addressing our two research questions via the previous sections of this paper.

\section{[Take in Table VI]}

In answering Research Question 1, it was found that research has tended to focus on a single stage or a subset of the four SCRM stages. While this is understandable, it means a holistic approach to studying the full SCRM process is missing (Gap 1). Such an approach is important in understanding the adoption of some Decision Support Systems (DSS) that benefit from a holistic approach to managing SCRs (Mogre et al., 2016). For work that is to focus on a particular SCRM stage, two key directions are identified. First, further research is required into classifying and prioritising risks in supply chains. Many studies provide typologies or taxonomies but rarely consider risk inter-relationships, interactions 
amongst risk drivers, or intangible factors in risk assessment. A few studies use ISM to identify risk inter-relationships but without proposing a risk categorisation. It is suggested that a more appropriate approach to risk categorisation is required, constituting a comprehensive risk structure with hierarchies and interactions (Gap 2). Second, the final stage of the SCRM process, i.e. risk monitoring, has received only limited attention to date (Gap 3) yet is an important part of the overall SCRM approach.

In terms of the pathway to SCRM, several researchers highlight the importance of coordination and collaboration with supply chain partners (e.g. Giunipero and Eltantawy, 2004; Faisal et al., 2007). Yet most SCRM research has been primarily conducted from a focal firm perspective and has not addressed the impact of the full complexity of interorganisational relationships on SCRM. Research suggests that building relationships and enhancing collaboration may provide more effective SCRM (e.g. Ojala and Hallikas, 2006; Ritchie and Brindley, 2007; Christopher et al., 2011; Kam et al., 2011; Hallikas and Lintukangas, 2016). Empirical evidence is however needed to reassess the general premise that more collaboration is better for the buyer as there is no added benefit from investing resources in managing risk in some situations (Hajmohammad and Vachon, 2016) and then to examine how to effectively bring traditional supplier and customer relationship management practices into SCRM (Gap 4). Much of the literature on the pathway to SCRM has focused on internal management decisions and capabilities (e.g., Riley et al., 2016). It has proposed SCRM strategies but rarely examined their motivating factors (Mishra et al., 2016), how these strategies evolve over time (Kaufmann et al., 2016), their effectiveness, or provided suitable guidance for managers on when and how to select the most appropriate strategy or replace existing but ineffective strategies. Thus, further research is needed to benchmark SCRM strategies (Gap 5) and develop more validated risk management strategies (Gap 6). It could also be helpful to examine the complementarity and balance between internal and external pathways to SCRM.

SCRM seeks to ensure profitability (e.g. Faisal et al., 2007), save costs (Manuj and Mentzer, 2008b) and potentially generate value (Trkman et al., 2016), meaning companies need to strike a balance between the benefits of SCRM and investments in these strategies. This relates to the probability and impact of risk events, but also to interactions between strategies, such as complementary or substitutable interactions (Zhen et al., 2016). Some strategies may have compounding effects, but the literature has paid limited attention to the effectiveness of combinations of strategies or how individual strategies could respond to multiple risks. In general, there is only limited work on the effect of SCRM on supply 


\section{Conclusions}

This paper has presented a SLR - a type of structured approach to conducting a search (Denyer and Tranfield, 2009; Saenz and Koufteros, 2015) - that is consistent with the frameworks recently outlined in the operations and SCM literature by Thomé et al. (2016) and Durach et al. (2017) but more specific to the topic of SCRM. In our study, we have used broad search terms to retrieve our initial set of articles thereby allowing us to capture relevant papers that use a variety of related terms. This approach retrieved a large number of articles that were then filtered down using our inclusion and exclusion criteria. This was a manual process but also meant that very few papers were added in at a later organic stage. The alternative would have been to use more specific keywords to search the literature and add in a greater number of papers organically, but such an approach would have increased the risk of missing some key articles.

Our SLR has provided a number of insights into the topic of SCRM. It is 
complementary to, but does not substitute, prior systematic reviews on SCR (Colicchia and Strozzi, 2012; Ghadge et al., 2012; Fischl et al., 2014; Fahimnia et al., 2015; Kilubi, 2016). We have presented our results based on a different approach to analysis than has been used in prior studies. Earlier work has used, for example, citation network analysis (Colicchia and Strozzi, 2012), text mining (Ghadge et al., 2012), and bibiometric \& network analysis (Fahimnia et al., 2015) whereas we have adopted a descriptive, thematic, and content analysis of the literature. It was found that there has been a considerable focus on identifying types of risks and proposing risk mitigation strategies. This includes the typology of risk factors in Rao and Goldsby (2009), which helps to understand the SCRs organisations might encounter thereby improving their risk identification; but such work needed to be connected with subsequent stages of SCRM.

Our paper encapsulates the four key stages of SCRM, i.e. risk identification, assessment, treatment, and monitoring, thereby responding to the observation by Ghadge et al. (2012) that a holistic approach to SCRM is missing. An overview of the entire SCRM field is provided, which complements prior reviews on specific topics that allow the reader to drill down deeper into particular areas, including price risk (Fischl et al., 2014) and quantitative models (Fahimnia et al., 2015). A holistic approach was needed at both a macro level, i.e. to cover the four stages of SCRM, but also at a more micro level. For example, within the SCRM stage of risk treatment, the focus is often on risk mitigation only and not on other treatment options such as risk avoidance or risk sharing. The most comprehensive of the non-systematic literature reviews was provided by Ho et al. (2015). Our paper is similar to this work in that it adopts a holistic approach and classifies the literature according to four stages of SCRM. Thus, both our paper and that by Ho et al. (2015) respond to Ghadge et al.'s (2012) call for holistic work on SCRM. But by taking a systematic approach, our review expands this earlier work to include further important literature on SCRM, including related to how SCRM is defined (e.g. Giunipero and Eltantawy, 2004; Manuj and Mentzer, 2008b; Wieland and Wallenburg, 2012) and the range of risk treatment options available. Moreover, we expand the scope of all prior reviews by including the most contemporary literature and by unpacking how theory has been used.

\section{Research Implications}

This study contributes to the SCRM literature in six key ways. First, we have provided a new and more comprehensive definition of SCRM. This enables researchers from different 
fields to develop a common understanding of SCRM for internal consistency and it facilitates potential application to the business world for external consistency. Second, we have proposed an OPO-based (objective-process-outcome) conceptual framework (Figure 2) that encapsulates the four SCRM stages and pathways to SCRM depending on the characteristics of the organisation and the objectives of SCRM. Third, we have provided a classification scheme for SCRM research (Tables II, III, and IV). This offers guidance to other researchers who can independently classify upcoming articles or choose larger samples. Fourth, we have created a $2 \times 2$ matrix that categorises risk treatment strategies based on the probability and impact of a risk (Figure 5). The prevalence of risk mitigation in the extant SCRM literature appears to have prevented the plurality of ideas in terms of how the various other treatment actions can be researched. Fifth, we have provided a first step towards understanding the use of theory in the SCRM literature. Four types of theory use are identified, which could inform future theory application and encourage further analyses to enrich findings. Sixth, we have identified ten key research gaps and suggested research questions for each gap. This represents a research agenda for the SCRM field.

\section{Practical Implications}

This review has three key managerial implications. First, our holistic approach to SCRM encourages managers to develop an orientation to the context as a whole so that they can form a complete picture of SCR and SCRM. It is important that managers consider the interrelatedness of the four stages, of SCRs, and of supply chain actors. For example, applying one treatment approach may be effective at mitigating a risk but it might induce another risk that then needs to be identified and assessed; or it may have consequences at other points in the supply chain. Joint decision making for selecting and implementing SCRM strategies - supported by software, such as what-if scenario planning tools - may therefore be appropriate. Second, we have highlighted the internal and external pathways that managers can adopt to manage SCRs. If SCRM is not coordinated internally with key stakeholders or there is a lack of external collaboration with supply chain partners, SCRM strategies may not have the desired outcomes. Third, our 2x2 matrix (Figure 5) provides guidance to managers on how to select appropriate risk treatment actions according to the characteristics of risks.

\section{Limitations}

Our analysis is limited by the availability and accessibility of relevant studies. Although we followed the SLR approach, it is still possible that some papers were missed. It seems 
likely however that this would be a small set of papers and would not dramatically alter the conclusions. Also, assessment of the articles was arguably subjective although the papers were reviewed by multiple researchers.

\section{References}

Aloini, D., Dulmin, R., Mininno, V. \& Ponticelli, S., (2012), "Supply chain management: a review of implementation risks in the construction industry", Business Process Management Journal, Vol. 18 No. 5, pp. 735-761.

Aqlan, F. \& Lam, S.S., (2015), "Supply chain risk modelling and mitigation", International Journal of Production Research, Vol. 53 No. 18, pp. 5640-5656.

Blackhurst, J.V., Scheibe, K.P. \& Johnson, D.J., (2008), "Supplier risk assessment and monitoring for the automotive industry”, International Journal of Physical Distribution \& Logistics Management, Vol. 38 No. 2, pp. 143-165.

Blome, C. \& Schoenherr, T., (2011), "Supply chain risk management in financial crises-A multiple case-study approach", International Journal of Production Economics, Vol. 134 No. 1, pp. 43-57.

Boyson, S., (2014), "Cyber supply chain risk management: Revolutionizing the strategic control of critical IT systems", Technovation, Vol. 34 No. 7, pp. 342-353.

Bradley, J.R., (2014), “An improved method for managing catastrophic supply chain disruptions”, Business Horizons, Vol. 57 No. 4, pp. 483-495.

Bühler, A., Wallenburg, C.M. \& Wieland, A., (2016), "Accounting for external turbulence of logistics organizations via performance measurement systems", Supply Chain Management: An International Journal, Vol. 21 No. 6, pp. 694-708.

Buzacott, J.A. \& Peng, H.S., (2012), "Contract design for risk sharing partnerships in manufacturing", European Journal of Operational Research, Vol. 218 No. 3, pp. 656-666.

Camuffo, A., Furlan, A. \& Rettore, E., (2007), "Risk sharing in supplier relations: an agency model for the Italian air-conditioning industry", Strategic Management Journal, Vol. 28 No. 12, pp. 1257-1266.

Cantor, D.E., Blackhurst, J., Pan, M.Y. \& Crum, M., (2014), "Examining the role of stakeholder pressure and knowledge management on supply chain risk and demand responsiveness", International Journal of Logistics Management, Vol. 25 No. 1, pp. 202-223.

Ceryno, P.S., Scavarda, L.F. \& Klingebiel, K., (2015), "Supply chain risk: empirical research in the automotive industry", Journal of Risk Research, Vol. 18 No. 9, pp. 1145-1164.

Chang, C.H., Xu, J.J. \& Song, D.P., (2015), "Risk analysis for container shipping: from a logistics perspective", International Journal of Logistics Management, Vol. 26 No. 1, pp. 147-171.

Chen, J., Sohal, A.S. \& Prajogo, D.I., (2016), "Supply risk mitigation: a multi-theoretical perspective", Production Planning \& Control, Vol. 27 No. 10, pp. 853-863.

Chopra, S. \& Sodhi, M., (2004), "Managing risk to avoid supply-chain breakdown", MIT Sloan Management Review, Vol. 46 No. 1, pp. 53-61.

Christopher, M., Mena, C., Khan, O. \& Yurt, O., (2011), "Approaches to managing global sourcing risk", Supply Chain Management: An International Journal, Vol. 16 No. 2, pp. 67-81.

Cohen, M.A. \& Kunreuther, H., (2007), “Operations risk management: Overview of Paul Kleindorfer's contributions", Production and Operations Management, Vol. 16 No. 5, pp. 525-541.

Colicchia, C. \& Strozzi, F., (2012), "Supply chain risk management: a new methodology for a systematic literature review", Supply Chain Management: An International Journal, Vol. 17 No. 4, pp. 403-418.

Craighead, C.W., Blackhurst, J., Rungtusanatham, M.J. \& Handfield, R.B., (2007), "The severity of supply chain disruptions: Design characteristics and mitigation capabilities", Decision Sciences, Vol. 38 No. 1, pp. 131-156.

Cruz, J.M. \& Liu, Z.G., (2011), "Modeling and analysis of the multiperiod effects of social relationship on supply chain networks", European Journal of Operational Research, Vol. 214 No. 1, pp. 39-52.

Denyer, D. \& Tranfield, D., (2009). Chapter 39: Producing a Systematic Review. In D.B. Buchanan, A. (ed.) The Sage Handbook of Organizational Research Methods. Sage Publications Ltd.: London, 671-689.

Diabat, A., Govindan, K. \& Panicker, V.V., (2012), "Supply chain risk management and its mitigation in a food industry", International Journal of Production Research, Vol. 50 No. 11, pp. 3039-3050.

Ellinger, A.E., Chen, H.Z., Tian, Y. \& Armstrong, C., (2015), "Learning orientation, integration, and supply chain risk management in Chinese manufacturing firms", International Journal of Logistics: Research and Applications, Vol. 18 No. 6, pp. 476-493.

Ellis, S.C., Henry, R.M. \& Shockley, J., (2010), "Buyer perceptions of supply disruption risk: A behavioral 
view and empirical assessment", Journal of Operations Management, Vol. 28 No. 1, pp. 34-46.

Ellis, S.C., Shockley, J. \& Henry, R.M., (2011), "Making Sense of Supply Disruption Risk Research: A Conceptual Framework Grounded in Enactment Theory", Journal of Supply Chain Management, Vol. 47 No. 2, pp. 65-96.

Enyinda, C.I., Mbah, C.H.N. \& Ogbuehi, A., (2010), "An empirical analysis of risk mitigation in the pharmaceutical industry supply chain: A developing-country perspective", Thunderbird International Business Review, Vol. 52 No. 1, pp. 45-54.

Fahimnia, B., Tang, C.S., Davarzani, H. \& Sarkis, J., (2015), "Quantitative models for managing supply chain risks: A review", European Journal of Operational Research, Vol. 247 No. 1, pp. 1-15.

Faisal, M.N., Banwet, D.K. \& Shankar, R., (2007), "Management of Risk in Supply Chains: SCOR Approach and Analytic Network Process", Supply Chain Forum: An International Journal, Vol. 8 No. 2, pp. 6679.

Fischl, M., Scherrer-Rathje, M. \& Friedli, T., (2014), "Digging deeper into supply risk: A systematic literature review on price risks", Supply Chain Management: An International Journal, Vol. 19 No. 480-503.

Gaudenzi, B. \& Borghesi, A., (2006), "Managing risks in the supply chain using the AHP method", International Journal of Logistics Management, Vol. 17 No. 1, pp. 114-136.

Ghadge, A., Dani, S. \& Kalawsky, R., (2012), "Supply chain risk management: present and future scope", International Journal of Logistics Management, Vol. 23 No. 3, pp. 313-339.

Giunipero, L.C. \& Eltantawy, R.A., (2004), "Securing the upstream supply chain: a risk management approach", International Journal of Physical Distribution \& Logistics Management, Vol. 34 No. 9, pp. 698-713.

Goh, M., Lim, J.Y.S. \& Meng, F.W., (2007), “A stochastic model for risk management in global supply chain networks", European Journal of Operational Research, Vol. 182 No. 1, pp. 164-173.

Govindan, K. \& Chaudhuri, A., (2016), "Interrelationships of risks faced by third party logistics service providers: A DEMATEL based approach", Transportation Research Part E: Logistics and Transportation Review, Vol. 90 No. 177-195.

Guertler, B. \& Spinler, S., (2015), "Supply risk interrelationships and the derivation of key supply risk indicators", Technological Forecasting and Social Change, Vol. 92 No. 224-236.

Hachicha, W. \& Elmsalmi, M., (2014), "An integrated approach based-structural modeling for risk prioritization in supply network management”, Journal of Risk Research, Vol. 17 No. 10, pp. 13011324.

Hajmohammad, S. \& Vachon, S., (2016), "Mitigation, Avoidance, or Acceptance? Managing Supplier Sustainability Risk", Journal of Supply Chain Management, Vol. 52 No. 2, pp. 48-65.

Hallikas, J. \& Lintukangas, K., (2016), "Purchasing and supply: An investigation of risk management performance", International Journal of Production Economics, Vol. 171 No. 487-494.

Hallikas, J., Virolainen, V.M. \& Tuominen, M., (2002), "Risk analysis and assessment in network environments: A dyadic case study", International Journal of Production Economics, Vol. 78 No. 1, pp. 45-55.

Heckmann, I., Comes, T. \& Nickel, S., (2015), “A critical review on supply chain risk - Definition, measure and modeling", Omega: The International Journal of Management Science, Vol. 52 No. 119-132.

Ho, W., Zheng, T., Yildiz, H. \& Talluri, S., (2015), "Supply chain risk management: a literature review", International Journal of Production Research, Vol. 53 No. 16, pp. 5031-5069.

Hoffmann, P., Schiele, H. \& Krabbendam, K., (2013), "Uncertainty, supply risk management and their impact on performance", Journal of Purchasing and Supply Management, Vol. 19 No. 3, pp. 199-211.

Hora, M. \& Klassen, R.D., (2013), "Learning from others' misfortune: Factors influencing knowledge acquisition to reduce operational risk", Journal of Operations Management, Vol. 31 No. 1-2, pp. 52 61.

Iso 31000, (2009). Risk management - Principles and guidelines: Geneva.

Jensen, J.D., Lawson, L.G. \& Lund, M., (2015), "Systemic cost-effectiveness analysis of food hazard reduction - Campylobacter in Danish broiler supply", European Journal of Operational Research, Vol. 241 No. 1, pp. 273-282.

Jia, F. \& Rutherford, C., (2010), "Mitigation of supply chain relational risk caused by cultural differences between China and the West", International Journal of Logistics Management, Vol. 21 No. 2, pp. 251-270.

Johnson, N., Elliott, D. \& Drake, P., (2013), "Exploring the role of social capital in facilitating supply chain resilience", Supply Chain Management: An International Journal, Vol. 18 No. 3, pp. 324-336.

Jüttner, U., (2005), "Supply chain risk management", International Journal of Logistics Management, Vol. 16 No. 1, pp. 120-141.

Jüttner, U., Peck, H. \& Christopher, M., (2003), "Supply chain risk management: outlining an agenda for future research", International Journal of Logistics: Research and Applications, Vol. 6 No. 4, pp. 
197-210.

Kam, B.H., Chen, L. \& Wilding, R., (2011), "Managing production outsourcing risks in China's apparel industry: a case study of two apparel retailers", Supply Chain Management: An International Journal, Vol. 16 No. 6, pp. 428-445.

Kaufmann, L., Carter, C.R. \& Rauer, J., (2016), "The Coevolution of Relationship Dominant Logic and Supply Risk Mitigation Strategies", Journal of Business Logistics, Vol. 37 No. 2, pp. 87-106.

Kayis, B. \& Karningsih, P.D., (2012), "A knowledge-based system tool for assisting manufacturing organizations in identifying supply chain risks", Journal of Manufacturing Technology Management, Vol. 23 No. 7, pp. 834-852.

Kern, D., Moser, R., Hartmann, E. \& Moder, M., (2012), "Supply risk management: model development and empirical analysis", International Journal of Physical Distribution \& Logistics Management, Vol. 42 No. 1, pp. 60-82.

Khan, O., Christopher, M. \& Burnes, B., (2008), “The impact of product design on supply chain risk: a case study", International Journal of Physical Distribution \& Logistics Management, Vol. 38 No. 5, pp. 412-432.

Kilubi, I., (2016), "The strategies of supply chain risk management - a synthesis and classification", International Journal of Logistics: Research and Applications, Vol. 19 No. 6, pp. 604-629.

Klassen, R.D. \& Vereecke, A., (2012), "Social issues in supply chains: Capabilities link responsibility, risk (opportunity), and performance", International Journal of Production Economics, Vol. 140 No. 1, pp. 103-115.

Lai, G.M., Debo, L.G. \& Sycara, K., (2009), "Sharing inventory risk in supply chain: The implication of financial constraint”, Omega: The International Journal of Management Science, Vol. 37 No. 4, pp. 811-825.

Larson, P.D. \& Halldorsson, A., (2004), "Logistics versus supply chain management: An international survey", International Journal of Logistics Research and Applications, Vol. 7 No. 1, pp. 17-31.

Lavastre, O., Gunasekaran, A. \& Spalanzani, A., (2012), "Supply chain risk management in French companies”, Decision Support Systems, Vol. 52 No. 4, pp. 828-838.

Lavastre, O., Gunasekaran, A. \& Spalanzani, A., (2014), "Effect of firm characteristics, supplier relationships and techniques used on Supply Chain Risk Management (SCRM): an empirical investigation on French industrial firms", International Journal of Production Research, Vol. 52 No. 11, pp. 33813403.

Li, G., Fan, H., Lee, P.K.C. \& Cheng, T.C.E., (2015), "Joint supply chain risk management: An agency and collaboration perspective", International Journal of Production Economics, Vol. 164 No. 83-94.

Lin, Y. \& Zhou, L., (2011), "The impacts of product design changes on supply chain risk: a case study", International Journal of Physical Distribution \& Logistics Management, Vol. 41 No. 2, pp. 162-186.

Manuj, I. \& Mentzer, J.T., (2008a), "Global Supply Chain Risk Management", Journal of Business Logistics, Vol. 29 No. 1, pp. 133-155.

Manuj, I. \& Mentzer, J.T., (2008b), “Global supply chain risk management strategies”, International Journal of Physical Distribution \& Logistics Management, Vol. 38 No. 3, pp. 192-223.

Matook, S., Lasch, R. \& Tamaschke, R., (2009), "Supplier development with benchmarking as part of a comprehensive supplier risk management framework", International Journal of Operations \& Production Management, Vol. 29 No. 3-4, pp. 241-267.

Mishra, D., Sharma, R.R.K., Kumar, S. \& Dubey, R., (2016), "Bridging and buffering: Strategies for mitigating supply risk and improving supply chain performance", International Journal of Production Economics, Vol. 180 No. 183-197.

Mogre, R., Talluri, S. \& D'amico, F., (2016), “A Decision Framework to Mitigate Supply Chain Risks: An Application in the Offshore-Wind Industry", IEEE Transactions on Engineering Management, Vol. 63 No. 3, pp. 316-325.

$\mathrm{Mu}$, E. \& Carroll, J., (2016), "Development of a fraud risk decision model for prioritizing fraud risk cases in manufacturing firms", International Journal of Production Economics, Vol. 173 No. 30-42.

Neiger, D., Rotaru, K. \& Churilov, L., (2009), "Supply chain risk identification with value-focused process engineering", Journal of Operations Management, Vol. 27 No. 2, pp. 154-168.

Nepal, B. \& Yadav, O.P., (2015), "Bayesian belief network-based framework for sourcing risk analysis during supplier selection”, International Journal of Production Research, Vol. 53 No. 20, pp. 6114-6135.

Nooraie, S.V. \& Parast, M.M., (2016), "Mitigating supply chain disruptions through the assessment of tradeoffs among risks, costs and investments in capabilities", International Journal of Production Economics, Vol. 171 No. 8-21.

Norrman, A. \& Jansson, U., (2004), “Ericsson's proactive supply chain risk management approach after a serious sub-supplier accident”, International Journal of Physical Distribution \& Logistics Management, Vol. 34 No. 5, pp. 434-456. 
Ojala, M. \& Hallikas, J., (2006), "Investment decision-making in supplier networks: Management of risk", International Journal of Production Economics, Vol. 104 No. 1, pp. 201-213.

Olson, D.L. \& Wu, D.S., (2011), "Risk management models for supply chain: a scenario analysis of outsourcing to China", Supply Chain Management: An International Journal, Vol. 16 No. 6, pp. 401408.

Painter, J., Borba, C., Hynes, M., Mays, D. \& Glanz, K., (2008), "The Use of Theory in Health Behavior Research from 2000 to 2005: A Systematic Review”, Annals of Behavioral Medicine, Vol. 35 No. 3 , pp. 358-362.

Park, K., Min, H. \& Min, S., (2016), "Inter-relationship among risk taking propensity, supply chain security practices, and supply chain disruption occurrence", Journal of Purchasing and Supply Management, Vol. 22 No. 2, pp. 120-130.

Peck, H., (2005), "Drivers of supply chain vulnerability: an integrated framework", International Journal of Physical Distribution \& Logistics Management, Vol. 35 No. 4, pp. 210-232.

Rajesh, R., Ravi, V. \& Venkata Rao, R., (2015), "Selection of risk mitigation strategy in electronic supply chains using grey theory and digraph-matrix approaches", International Journal of Production Research, Vol. 53 No. 1, pp. 238-257.

Rangel, D.A., De Oliveira, T.K. \& Leite, M.S.A., (2015), "Supply chain risk classification: discussion and proposal", International Journal of Production Research, Vol. 53 No. 22, pp. 6868-6887.

Rao, S. \& Goldsby, T.J., (2009), "Supply chain risks: a review and typology", International Journal of Logistics Management, Vol. 20 No. 1, pp. 97-123.

Riley, J.M., Klein, R., Miller, J. \& Sridharan, V., (2016), "How internal integration, information sharing, and training affect supply chain risk management capabilities", International Journal of Physical Distribution \& Logistics Management, Vol. 46 No. 10, pp. 953-980.

Ritchie, B. \& Brindley, C., (2007), "An emergent framework for supply chain risk management and performance measurement", Journal of the Operational Research Society, Vol. 58 No. 11, pp. 13981411.

Roehrich, J.K., Grosvold, J. \& Hoejmose, S.U., (2014), "Reputational risks and sustainable supply chain management Decision making under bounded rationality”, International Journal of Operations \& Production Management, Vol. 34 No. 5, pp. 695-719.

Saenz, M.J. \& Koufteros, X., (2015), "Literature reviews in supply chain management and logistics", International Journal of Physical Distribution \& Logistics Management, Vol. 45 No. 1/2, pp.

Sarker, S., Engwall, M., Trucco, P. \& Feldmann, A., (2016), "Internal Visibility of External Supplier Risks and the Dynamics of Risk Management Silos", IEEE Transactions on Engineering Management, Vol. 63 No. 4, pp. 451-461.

Scheller-Wolf, A. \& Tayur, S., (2009), "Risk sharing in supply chains using order bands-Analytical results and managerial insights", International Journal of Production Economics, Vol. 121 No. 2, pp. 715727.

Schoenherr, T., Rao Tummala, V.M. \& Harrison, T.P., (2008), “Assessing supply chain risks with the analytic hierarchy process: Providing decision support for the offshoring decision by a US manufacturing company", Journal of Purchasing and Supply Management, Vol. 14 No. 2, pp. 100-111.

Silbermayr, L. \& Minner, S., (2016), "Dual sourcing under disruption risk and cost improvement through learning", European Journal of Operational Research, Vol. 250 No. 1, pp. 226-238.

Simangunsong, E., Hendry, L.C. \& Stevenson, M., (2016), "Managing supply chain uncertainty with emerging ethical issues", International Journal of Operations \& Production Management, Vol. 36 No. 10, pp. 1272-1307.

Sinha, P.R., Whitman, L.E. \& Malzahn, D., (2004), "Methodology to mitigate supplier risk in an aerospace supply chain", Supply Chain Management: An International Journal, Vol. 9 No. 2, pp. 154-168.

Sodhi, M.S., Son, B.-G. \& Tang, C.S., (2012), "Researchers' Perspectives on Supply Chain Risk Management", Production and Operations Management, Vol. 21 No. 1, pp. 1-13.

Speier, C., Whipple, J.M., Closs, D.J. \& Voss, M.D., (2011), "Global supply chain design considerations: Mitigating product safety and security risks”, Journal of Operations Management, Vol. 29 No. 7, pp. 721-736.

Tang, C.S., (2006), "Perspectives in supply chain risk management", International Journal of Production Economics, Vol. 103 No. 2, pp. 451-488.

Tang, O. \& Musa, S.N., (2011), "Identifying risk issues and research advancements in supply chain risk management", International Journal of Production Economics, Vol. 133 No. 1, pp. 25-34.

Thun, J.H. \& Hoenig, D., (2011), “An empirical analysis of supply chain risk management in the German automotive industry”, International Journal of Production Economics, Vol. 131 No. 1, pp. 242-249.

Tranfield, D., Denyer, D. \& Smart, P., (2003), “Towards a Methodology for Developing Evidence-Informed Management Knowledge by Means of Systematic Review”, British Journal of Management, Vol. 14 
No. 3, pp. 207-222.

Trkman, P., De Oliveira, M.P.V. \& Mccormack, K., (2016), "Value-oriented supply chain risk management: you get what you expect”, Industrial Management \& Data Systems, Vol. 116 No. 5, pp. 1061-1083.

Tsai, M.C., Liao, C.H. \& Han, C.S., (2008), "Risk perception on logistics outsourcing of retail chains: model development and empirical verification in Taiwan", Supply Chain Management: An International Journal, Vol. 13 No. 6, pp. 415-424.

Tummala, R. \& Schoenherr, T., (2011), "Assessing and managing risks using the supply chain risk management process (SCRMP)", Supply Chain Management: An International Journal, Vol. 16 No. 6, pp. 474-483.

Venkatesh, V.G., Rathi, S. \& Patwa, S., (2015), “Analysis on supply chain risks in Indian apparel retail chains and proposal of risk prioritization model using Interpretive structural modeling", Journal of Retailing and Consumer Services, Vol. 26 No. 153-167.

Wagner, S.M. \& Bode, C., (2006), “An empirical investigation into supply chain vulnerability", Journal of Purchasing and Supply Management, Vol. 12 No. 6, pp. 301-312.

Wever, M., Wognum, P.M., Trienekens, J.H. \& Omta, S.W.F., (2012), "Supply Chain-Wide Consequences of Transaction Risks and Their Contractual Solutions: Towards an Extended Transaction Cost Economics Framework", Journal of Supply Chain Management, Vol. 48 No. 1, pp. 73-91.

Wieland, A. \& Wallenburg, C.M., (2012), "Dealing with supply chain risks Linking risk management practices and strategies to performance", International Journal of Physical Distribution \& Logistics Management, Vol. 42 No. 10, pp. 887-905.

Xie, K.F., Liu, J.M., Peng, H.T., Chen, G. \& Chen, Y., (2009), "Early-warning management of inner logistics risk in SMEs based on label-card system", Production Planning \& Control, Vol. 20 No. 4, pp. 306319.

Yang, B. \& Yang, Y., (2010), "Postponement in supply chain risk management: a complexity perspective", International Journal of Production Research, Vol. 48 No. 7, pp. 1901-1912.

Zhen, X.P., Li, Y.J., Cai, G.S. \& Shi, D., (2016), "Transportation disruption risk management: business interruption insurance and backup transportation", Transportation Research Part E: Logistics and Transportation Review, Vol. 90 No. 51-68.

Zsidisin, G.A., (2003), "A grounded definition of supply risk”, Journal of Purchasing and Supply Management, Vol. 9 No. 5, pp. 217-224.

Zsidisin, G.A., Ellram, L.M., Carter, J.R. \& Cavinato, J.L., (2004), “An analysis of supply risk assessment techniques", International Journal of Physical Distribution \& Logistics Management, Vol. 34 No. 5, pp. 397-413.

Zsidisin, G.A., Melnyk, S.A. \& Ragatz, G.L., (2005), “An institutional theory perspective of business continuity planning for purchasing and supply management", International Journal of Production Research, Vol. 43 No. 16, pp. 3401-3420.

About the Authors

Yiyi Fan: Yiyi Fan is a PhD candidate in the Department of Management Science at Lancaster University Management School, UK. She obtained her MSc in Operations, Project and Supply Chain Management at the University of Manchester. Her current research focuses on buyersupplier relationships and supply chain risk management. She has presented her research at European Operations Management Association (EurOMA) doctoral seminars and at the main EurOMA conference.

Professor Mark Stevenson: Mark Stevenson is a Professor of Operations Management at Lancaster University Management School, UK. His research interests include socially sustainable supply chain management, supply chain risk \& resilience, supply chain flexibility, and production planning \& control in high-variety contexts. Mark is a member of the European 
Operations Management Association (EurOMA), and his work has appeared in various operations management journals, including the International Journal of Operations \& Production Management (IJOPM), Production \& Operations Management (POM), the International Journal of Production Economics (IJPE), and the International Journal of Production Research (IJPR). 
Table I: Definitions of SCRM in the Literature

\begin{tabular}{|c|c|c|c|c|c|c|c|c|c|c|c|}
\hline \multirow[t]{2}{*}{ Characteristics } & \multicolumn{4}{|c|}{ Process } & \multicolumn{3}{|c|}{ Pathway } & \multicolumn{4}{|c|}{ Objective } \\
\hline & 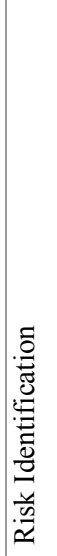 & 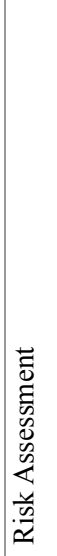 & 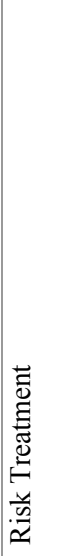 & 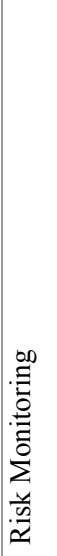 & 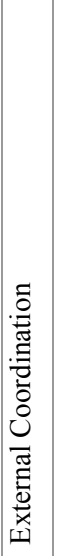 & 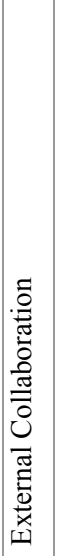 & 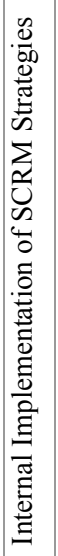 & 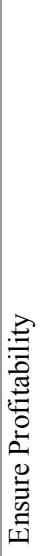 & 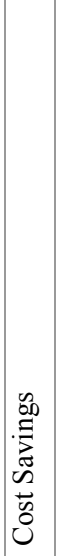 & 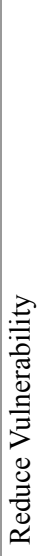 & 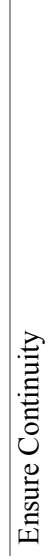 \\
\hline Jüttner et al. (2003, p. 201) and Jüttner (2005, p. 124) & $\mathrm{X}$ & & $\mathrm{X}$ & & $\mathrm{X}$ & & & & & $\mathrm{X}$ & \\
\hline Giunipero and Eltantawy (2004, p. 703) & & & & $\mathrm{X}$ & $\mathrm{X}$ & & & & & & \\
\hline Norrman and Jansson $(2004$, p. 436) & & & $\mathrm{X}$ & & & $\mathrm{X}$ & $\mathrm{X}$ & & & & \\
\hline Tang (2006, p. 453) & & & $\mathrm{X}$ & & $\mathrm{X}$ & $\mathrm{X}$ & & $\mathrm{X}$ & & & $\mathrm{X}$ \\
\hline Faisal et al. $(2007$, p. 68$)$ & & & $\mathrm{X}$ & & $\mathrm{X}$ & $\mathrm{X}$ & $\mathrm{X}$ & $\mathrm{X}$ & & & $\mathrm{X}$ \\
\hline Goh et al. $(2007$, p. $164-165)$ & $\mathrm{X}$ & & $\mathrm{X}$ & & $\mathrm{X}$ & & & & & $\mathrm{X}$ & \\
\hline Manuj and Mentzer (2008b, p. 205) & $\mathrm{X}$ & $\mathrm{X}$ & $\mathrm{X}$ & & $\mathrm{X}$ & & $\mathrm{X}$ & $\mathrm{X}$ & $\mathrm{X}$ & & \\
\hline Lavastre et al. $(2012$, p. 830$)$ & & $\mathrm{X}$ & $\mathrm{X}$ & & & & & & & & \\
\hline Wieland and Wallenburg (2012, p. 890-891) & $\mathrm{X}$ & $\mathrm{X}$ & $\mathrm{X}$ & $\mathrm{X}$ & & & & & & $\mathrm{X}$ & $\mathrm{X}$ \\
\hline Ho et al. $(2015$, p. 5036$)$ & $\mathrm{X}$ & $\mathrm{X}$ & $\mathrm{X}$ & $\mathrm{X}$ & & $\mathrm{X}$ & & & & & \\
\hline
\end{tabular}


Table II: Descriptive Analysis of Country, Industry Sector, and Research Perspective

\begin{tabular}{|c|c|c|c|c|}
\hline Code & \multicolumn{2}{|c|}{ Description } & $\begin{array}{c}\text { No. } \\
\text { Papers }\end{array}$ & $\begin{array}{c}\text { \% of Total } \\
\text { (354 Papers) }\end{array}$ \\
\hline \multirow{6}{*}{ Country } & \multirow{2}{*}{$\begin{array}{c}\text { Single } \\
\text { Country } \\
(\mathbf{3 0} \%)\end{array}$} & Developed Country & 60 & $17 \%$ \\
\hline & & Developing Country & 46 & $13 \%$ \\
\hline & \multirow{3}{*}{$\begin{array}{c}\text { Multiple } \\
\text { Countries } \\
(6 \%)\end{array}$} & Developed Countries & 9 & $3 \%$ \\
\hline & & Developing Countries & 2 & $0.6 \%$ \\
\hline & & $\begin{array}{l}\text { Developed and } \\
\text { Developing Countries }\end{array}$ & 7 & $2 \%$ \\
\hline & 3 & Total & 124 & $35 \%$ \\
\hline \multirow{3}{*}{ Industry } & 8 & Single Industry & 115 & $32 \%$ \\
\hline & $2 p$ & Multiple Industries & 70 & $20 \%$ \\
\hline & 2 & Total & 185 & $52 \%$ \\
\hline \multirow{5}{*}{$\begin{array}{c}\text { Research } \\
\text { Perspective }\end{array}$} & $\sqrt{3}$ & Supplier's Perspective & 5 & $1.4 \%$ \\
\hline & & Buyer's Perspective & 88 & $25 \%$ \\
\hline & & Dyadic Perspective & 15 & $4 \%$ \\
\hline & & Triadic Perspective & 7 & $2 \%$ \\
\hline & & Total & 115 & $32 \%$ \\
\hline
\end{tabular}


Table III: Number of Articles by Research Method

\begin{tabular}{|c|c|c|c|c|c|}
\hline \multicolumn{4}{|c|}{ Research Method } & \multirow{2}{*}{$\begin{array}{c}\begin{array}{c}\text { No. } \\
\text { Papers }\end{array} \\
15\end{array}$} & \multirow{2}{*}{$\begin{array}{c}\text { \% of Total } \\
\text { Papers }\end{array}$} \\
\hline \multirow{14}{*}{$\begin{array}{l}\text { Single } \\
\text { Research } \\
\text { Method } \\
(99 \%)\end{array}$} & \multirow{3}{*}{$\begin{array}{c}\text { Conceptual } \\
\text { (18\%) }\end{array}$} & \multirow{2}{*}{$\begin{array}{c}\text { Literature } \\
\text { Review }(6 \%)\end{array}$} & Traditional Literature Review & & \\
\hline & & & Systematic Literature Review & 5 & $1.4 \%$ \\
\hline & & & Other Conceptual Research & 43 & $12.1 \%$ \\
\hline & & Case Study & Single Case Study & 55 & $15.5 \%$ \\
\hline & & $(29 \%)$ & Multiple Case Study & 48 & $13.6 \%$ \\
\hline & Empirical & 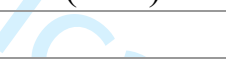 & Survey & 55 & $15.5 \%$ \\
\hline & $(47 \%)$ & 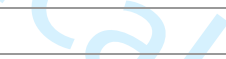 & Action Research & 4 & $1.1 \%$ \\
\hline & & $y$ & Experiment & 3 & $0.8 \%$ \\
\hline & & & Grounded Theory & 2 & $0.6 \%$ \\
\hline & & & Mathematical & 67 & $18.9 \%$ \\
\hline & Analytical & & Simulation & 40 & $11.3 \%$ \\
\hline & $(32 \%)$ & & Multi-agent & 2 & $0.6 \%$ \\
\hline & & & Programming & 4 & $1.1 \%$ \\
\hline & & & Secondary Data $(2 \%)$ & 7 & $2 \%$ \\
\hline & & & Mixed Research Method (1\%) & 4 & $1.1 \%$ \\
\hline & & & Total & 354 & $100 \%$ \\
\hline
\end{tabular}


Table IV: SCRM Process Coding Scheme

\begin{tabular}{|c|c|c|c|c|}
\hline SCRM Process & \multicolumn{2}{|c|}{ Sub Classification Codes } & $\begin{array}{c}\text { No. } \\
\text { Papers }\end{array}$ & \% of Total Papers (339 Papers) \\
\hline \multirow{7}{*}{ Risk Identification } & \multicolumn{2}{|l|}{ Drivers of SCR } & 16 & $4.7 \%$ \\
\hline & \multicolumn{2}{|l|}{ Sources of SCR } & 18 & $5.3 \%$ \\
\hline & \multirow{3}{*}{ Classify types of SCR } & Classification Categories Only & 20 & $5.9 \%$ \\
\hline & & List Risks in Each Category & 53 & $16 \%$ \\
\hline & & List of Risks Without Categorising & 18 & $5.3 \%$ \\
\hline & \multicolumn{2}{|c|}{ Proposed Strategies } & 12 & $3.5 \%$ \\
\hline & \multicolumn{2}{|c|}{ Applied Strategies } & 18 & $5.3 \%$ \\
\hline \multirow{4}{*}{ Risk Assessment } & \multicolumn{2}{|l|}{ Risk Prioritisation } & 9 & $2.6 \%$ \\
\hline & \multicolumn{2}{|l|}{ Risk Inter-relationship } & 16 & $4.7 \%$ \\
\hline & \multicolumn{2}{|l|}{ Applied Strategies } & 62 & $18.3 \%$ \\
\hline & \multicolumn{2}{|l|}{ Proposed Strategies } & 26 & $7.7 \%$ \\
\hline \multirow{9}{*}{ Risk Treatment } & \multicolumn{2}{|l|}{ Risk Acceptance } & 3 & $0.9 \%$ \\
\hline & \multicolumn{2}{|l|}{ Risk Avoidance } & 8 & $2.4 \%$ \\
\hline & \multicolumn{2}{|l|}{ Risk Transfer } & 6 & $1.8 \%$ \\
\hline & \multirow{4}{*}{ Risk Mitigation } & Proposed Strategies & 185 & $54.6 \%$ \\
\hline & & Applied Strategies & 16 & $4.7 \%$ \\
\hline & & Enabler \& Antecedents & 31 & $9.1 \%$ \\
\hline & & $\begin{array}{l}\text { Benchmarking and Evaluating Mitigation } \\
\text { Strategies }\end{array}$ & 16 & $4.7 \%$ \\
\hline & \multicolumn{2}{|l|}{ Risk Sharing } & 14 & $4.1 \%$ \\
\hline & \multicolumn{2}{|l|}{ Miscellaneous } & 5 & $1.5 \%$ \\
\hline \multirow{2}{*}{ Risk Monitoring } & \multicolumn{2}{|l|}{ Proposed Strategies } & 8 & $2.4 \%$ \\
\hline & \multicolumn{2}{|l|}{ Applied Strategies } & 2 & $0.6 \%$ \\
\hline
\end{tabular}


Table V: Frequency of Theory Use in the Extant Literature by Year

\begin{tabular}{|c|c|c|c|c|c|c|c|c|c|c|c|c|c|c|c|c|c|c|c|c|c|c|c|c|c|c|}
\hline & 2000 & 2001 & 2002 & 2003 & 2004 & 2005 & 2006 & 2007 & 2008 & 2009 & 2010 & 2011 & 2012 & & & 2013 & & 2014 & & 2015 & 2016 & & Tota & & & $\%$ of Total \\
\hline Theory Use & I A T B & I A T B & I A T B & I A T B & I A T B & I A T B & I A T B & 3 I A T B & 1 A T B & 3 I A T B & B I A T B & I A T B & I A T & B & & A T B & & A T B & B I & A T B & 3 I A T B & B I A & & & ota ${ }^{\%}$ & \\
\hline TCE & & & 111 & & 1 & & 1 & & 1 & & 1 & 1 & & 1 & & 1 & & & & & & 43 & & 1 & 9 & $17 \%$ \\
\hline Agency Theory & & & & 1 & 1 & & & 1 & 1 & & & & & & & & & 1 & & & 1 & 14 & 41 & 0 & 6 & $11 \%$ \\
\hline System Theory & & & & & 1 & 1 & & & & & & & & & & & & & 1 & & & 30 & 00 & 0 & 3 & $6 \%$ \\
\hline Institution Theory & & & & & & 1 & & & & & & & & & & & & & & & 1 & 11 & & $\mathbf{0}$ & 2 & $4 \%$ \\
\hline RBV & & & & & & & 1 & & 1 & 1 & & & & & & & & & & & 1 & 22 & 20 & 0 & 4 & $8 \%$ \\
\hline Resource Dependence Theory & & & & & & & & & 1 & & 1 & & & & & & & & & & 1 & 21 & & 0 & 3 & $6 \%$ \\
\hline Contingency Theory & & & & & & & & & & 1 & & & & & 1 & & & & 1 & & 2 & 32 & 20 & 0 & 5 & $9 \%$ \\
\hline Normal Accident Theory & & & & & & & & & & & 1 & 1 & & & & & & 1 & & & 1 & 12 & 21 & 0 & 4 & $8 \%$ \\
\hline Real Option Theory & & & & & & & & & & & 1 & & & & & & & & & & & 00 & & 0 & 1 & $2 \%$ \\
\hline Enactment Theory & & & & & & & & & & & & 1 & & & & & & & & & & 01 & 10 & 0 & 1 & $2 \%$ \\
\hline High Reliability Theory & & & & & & & & & & & & 1 & & & & & & & & & 1 & 11 & & 0 & 2 & $4 \%$ \\
\hline Social Capital Theory & & & & & & & & & & & & & 1 & & & 1 & & 1 & & & & 03 & 30 & 0 & 3 & $6 \%$ \\
\hline Modular Systems Theory & & & & & & & & & & & & & & & & 1 & & & & & & 00 & $\begin{array}{lll}0 & 1\end{array}$ & 0 & 1 & $2 \%$ \\
\hline Stakeholder Theory & & & & & & & & & & & & & & & & & & 1 & & & & 11 & 10 & 0 & 2 & $4 \%$ \\
\hline Regulatory Focus Theory & & & & & & & & & & & & & & & & & & 1 & & & & 00 & 01 & 0 & 1 & $2 \%$ \\
\hline KBV & & & & & & & & & & & & & & & & & & & & 1 & & 00 & $\begin{array}{lll}0 & 1\end{array}$ & 0 & 1 & $2 \%$ \\
\hline Manufacturing Strategy Theory & & & & & & & & & & & & & & & & & & & & & 1 & 10 & 00 & 0 & 1 & $2 \%$ \\
\hline Expectation Confirmation Theory & & & & & & & & & & & & & & & & & & & & & 1 & 01 & 10 & 0 & 1 & $2 \%$ \\
\hline Information Processing Theory & & & & & & & & & & & & & & & & & & & & & 2 & 02 & 20 & 0 & 2 & $4 \%$ \\
\hline Complementarity Theory & & & & & & & & & & & & & & & & & & & & & 1 & 01 & & 0 & 1 & $2 \%$ \\
\hline Total & & & 111 & 1 & \begin{tabular}{|l|l|l|l|l|l|l|l}
2 & 1
\end{tabular} & 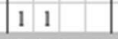 & 2 & 1 & 22 & 2 & 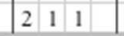 & $\begin{array}{lll}1 & 3\end{array}$ & 1 & 1 & & 12 & 1 : & $\begin{array}{ll}32 & 2\end{array}$ & 2 & 1 & 58 & 2025 & 257 & 1 & 53 & $100 \%$ \\
\hline
\end{tabular}

Note: I: Informed by theory; A: Applying theory; T: Testing theory; B: Building theory

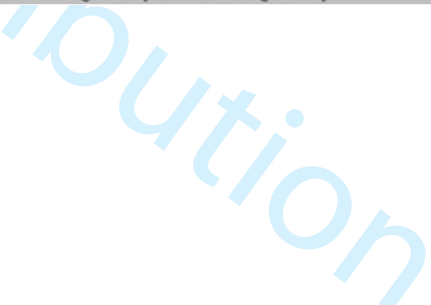


Table VI: From Present to Future - Research Questions for the Identified Research Gaps

\begin{tabular}{|c|c|c|c|c|}
\hline Gap & \multicolumn{2}{|c|}{ Starting From } & Description (Present) & $\begin{array}{c}\text { Example Research Questions } \\
\text { (Future) }\end{array}$ \\
\hline 1 & \multirow{7}{*}{ RQ1 } & \multirow{3}{*}{$\begin{array}{l}\text { Four SCRM } \\
\text { stages }\end{array}$} & $\begin{array}{l}\text { Limited research has adopted } \\
\text { a holistic approach to the } \\
\text { SCRM process }\end{array}$ & $\begin{array}{l}\text { How can SCRM research be } \\
\text { conducted from a holistic } \\
\text { perspective? How are the } 4 \text { SCRM } \\
\text { stages inter-related? }\end{array}$ \\
\hline 2 & & & $\begin{array}{l}\text { A holistic risk categorisation } \\
\text { structure is needed to classify } \\
\text { and prioritise risks, identify } \\
\text { inter-relationships, and } \\
\text { consider intangible factors in } \\
\text { risk assessment. }\end{array}$ & $\begin{array}{l}\text { What methods can be used to } \\
\text { classify, prioritise and identify risk } \\
\text { inter-relationships in a hierarchical } \\
\text { structure? How are SCRs inter- } \\
\text { related, and what does this mean } \\
\text { for SCRM? What intangible factors } \\
\text { need to be considered in risk } \\
\text { assessment? }\end{array}$ \\
\hline 3 & & & $\begin{array}{l}\text { Risk monitoring has received } \\
\text { limited attention. }\end{array}$ & $\begin{array}{l}\text { What methods and strategies can be } \\
\text { used to monitor SCRs during the } \\
\text { SCRM process? }\end{array}$ \\
\hline 4 & & \multirow{3}{*}{$\begin{array}{l}\text { Pathway to } \\
\text { SCRM }\end{array}$} & $\begin{array}{l}\text { There is a need to } \\
\text { disentangle the role of dyadic } \\
\text { supply chain relationships in } \\
\text { the SCRM process. }\end{array}$ & $\begin{array}{l}\text { How does the nature of the buyer- } \\
\text { supplier relationship affect SCRs } \\
\text { and the SCRM process? }\end{array}$ \\
\hline 5 & & & $\begin{array}{l}\text { Benchmarking of SCRM } \\
\text { strategies is needed to } \\
\text { identify promising practices. }\end{array}$ & $\begin{array}{l}\text { How can firms benchmark SCRM } \\
\text { strategies? }\end{array}$ \\
\hline 6 & & & $\begin{array}{l}\text { SCRM strategies that provide } \\
\text { guidance for practitioners } \\
\text { need to be developed. }\end{array}$ & $\begin{array}{l}\text { What SCRM strategies are } \\
\text { appropriate for practitioners? }\end{array}$ \\
\hline 7 & & $\begin{array}{l}\text { Goal of } \\
\text { SCRM }\end{array}$ & $\begin{array}{l}\text { A cost-benefit analysis of } \\
\text { SCRM is needed. }\end{array}$ & $\begin{array}{l}\text { How can firms best trade-off the } \\
\text { costs and benefits of SCRM? }\end{array}$ \\
\hline 8 & RQ2 & Theory & $\begin{array}{l}\text { Theories need to be } \\
\text { employed more appropriately } \\
\text { to deepen understanding of } \\
\text { SCRM and add external } \\
\text { validity. }\end{array}$ & $\begin{array}{l}\text { How can theories be used to } \\
\text { improve our understanding of } \\
\text { SCRM? }\end{array}$ \\
\hline 9 & \multirow[t]{2}{*}{ RQ1+RQ2 } & $\begin{array}{l}\text { Research } \\
\text { Context }\end{array}$ & $\begin{array}{l}\text { Insufficient understanding of } \\
\text { SCRM in developing country } \\
\text { contexts. }\end{array}$ & $\begin{array}{l}\text { How does country context } \\
\text { influence SCRM? }\end{array}$ \\
\hline 10 & & $\begin{array}{l}\text { Research } \\
\text { Perspective }\end{array}$ & $\begin{array}{l}\text { More research is needed } \\
\text { from the supplier } \\
\text { perspective. }\end{array}$ & $\begin{array}{l}\text { How does supply chain position } \\
\text { affect SCRM? }\end{array}$ \\
\hline
\end{tabular}


Figure 1: Systematic Literature Review Process (adapted from Tranfield et al., 2003)

\begin{tabular}{|c|c|}
\hline \multicolumn{2}{|c|}{ Stage 1: Question Formulation } \\
\hline \multicolumn{2}{|c|}{$\begin{array}{l}\text { SLR Research Questions: } \\
\text { 1. What is the current state-of-the-art in SCRM research on risk identification, risk assessment, risk treatment, and risk monitoring? } \\
\text { 2. How has theory been used in SCRM research? }\end{array}$} \\
\hline \multicolumn{2}{|c|}{ Stage 2: Keyword Search in Identified Databases } \\
\hline Criteria & Rationale \\
\hline 1. Keywords: "supply chain" AND "risk" & $\begin{array}{l}\text { As used by Ho et al. (2015), broad keywords allowed to } \\
\text { thoroughly uncover all the relevant literature. }\end{array}$ \\
\hline $\begin{array}{l}\text { 2. Business Source Complete Database (BSR) and Web of } \\
\text { Science Database (WoS) }\end{array}$ & $\begin{array}{l}\text { These databases were selected as they have arguably the best } \\
\text { coverage of operations and supply chain and management and } \\
\text { are typically used in literature reviews (e.g. Gimenez and } \\
\text { Tachizawa, 2012). }\end{array}$ \\
\hline 3. International peer-reviewed academic journals selected & $\begin{array}{l}\text { In an attempt to include high-quality scientific studies in English } \\
\text { and exclude books, book chapters, conference proceedings, } \\
\text { dissertations, and working papers. }\end{array}$ \\
\hline 4. Time range: January 2000 to December 2016 & $\begin{array}{l}\text { Focused on 2000-2016 to develop a contemporary } \\
\text { understanding of the phenomenon. In addition, the back- } \\
\text { tracking method (Olhager et al., 2015) was used to find the most } \\
\text { relevant earlier stuides (prior to 2000). }\end{array}$ \\
\hline \multicolumn{2}{|c|}{ Number of Selected Papers in Stage 2: $\mathbf{5 4 1 2}=2272(\mathrm{BSR})+3140(\mathrm{WoS})$} \\
\hline
\end{tabular}

\begin{tabular}{|c|c|}
\hline \multicolumn{2}{|c|}{ Stage 3: Removal of Duplicates (1262) } \\
\hline \multicolumn{2}{|c|}{ Number of Selected Papers in Stage 3: $4150(=5412-1262)$} \\
\hline \multicolumn{2}{|c|}{ Stage 4: Article Quality and Relevance Assessment } \\
\hline Criteria & Rationale \\
\hline $\begin{array}{l}\text { 1. Eliminated articles published in journals that are not listed in } \\
\text { the ABS Academic Journal Quality Guide } 2015 \text { (1763 articles) }\end{array}$ & $\begin{array}{l}\text { We chose the ABS Guide as it was found to be the most widely } \\
\text { used and accepted quality indicator in the academic world } \\
\text { (Ghadge et al., 2012). }\end{array}$ \\
\hline $\begin{array}{l}\text { 2. Irrelevant articles were removed after title and abstract } \\
\text { analysis ( } 1677 \text { articles) }\end{array}$ & $\begin{array}{l}\text { These papers were excluded as they are not contributing to } \\
\text { answering the research questions. }\end{array}$ \\
\hline $\begin{array}{l}\text { 3. Less relevant articles were removed after full-text scanning } \\
\text { (365 articles) }\end{array}$ & $\begin{array}{l}\text { These papers were excluded as their main focus is not on any } \\
\text { stage of the SCRM process. }\end{array}$ \\
\hline \multicolumn{2}{|c|}{ Number of Selected Papers in Stage 4: $345(=4150-1763-1677-365)$} \\
\hline \multicolumn{2}{|c|}{ Stage 5: Capturing Other Relevant Articles } \\
\hline Criteria & Rationale \\
\hline $\begin{array}{l}\text { 1. Five articles added into database through citation checking } \\
\text { process }\end{array}$ & $\begin{array}{l}\text { Used forward-tracking method (Olhager et al., 2015) to include } \\
\text { articles that referred to central sources. }\end{array}$ \\
\hline $\begin{array}{l}\text { 2. Four articles that meet above criteria (see Stage } 4 \text { ) have been } \\
\text { found in Google Scholar }\end{array}$ & $\begin{array}{l}\text { In an attempt to ascertain whether a list of peer-reviewed papers } \\
\text { may be available through other databases. }\end{array}$ \\
\hline \multicolumn{2}{|c|}{ Number of Selected Papers in Stage 5: $354(=345+5+4)$} \\
\hline \multicolumn{2}{|c|}{ Stage 6: Full-Text Analysis and Coding } \\
\hline \multicolumn{2}{|c|}{$\begin{array}{l}\text { 1. Full-text analysis of } 354 \text { papers } \\
\text { 2. Use NVivo to create a list of classification codes covering country, industry sector, adopted theory, research perspective, research } \\
\text { method, the four stages in the SCRM process. }\end{array}$} \\
\hline \multicolumn{2}{|c|}{ Number of Selected Papers in Stage 6: 354} \\
\hline \multicolumn{2}{|c|}{ Stage 7: Reporting } \\
\hline $\begin{array}{l}\text { 1. Descriptive analysis on country, industry sector, research per } \\
\text { 2. Thematic analysis on the four stages in the SCRM process an }\end{array}$ & $\begin{array}{l}\text { ctive, and research method } \\
\text { he use of theory }\end{array}$ \\
\hline
\end{tabular}


Figure 2: Objective-Process-Outcome (OPO) Based SCRM Conceptual Framework

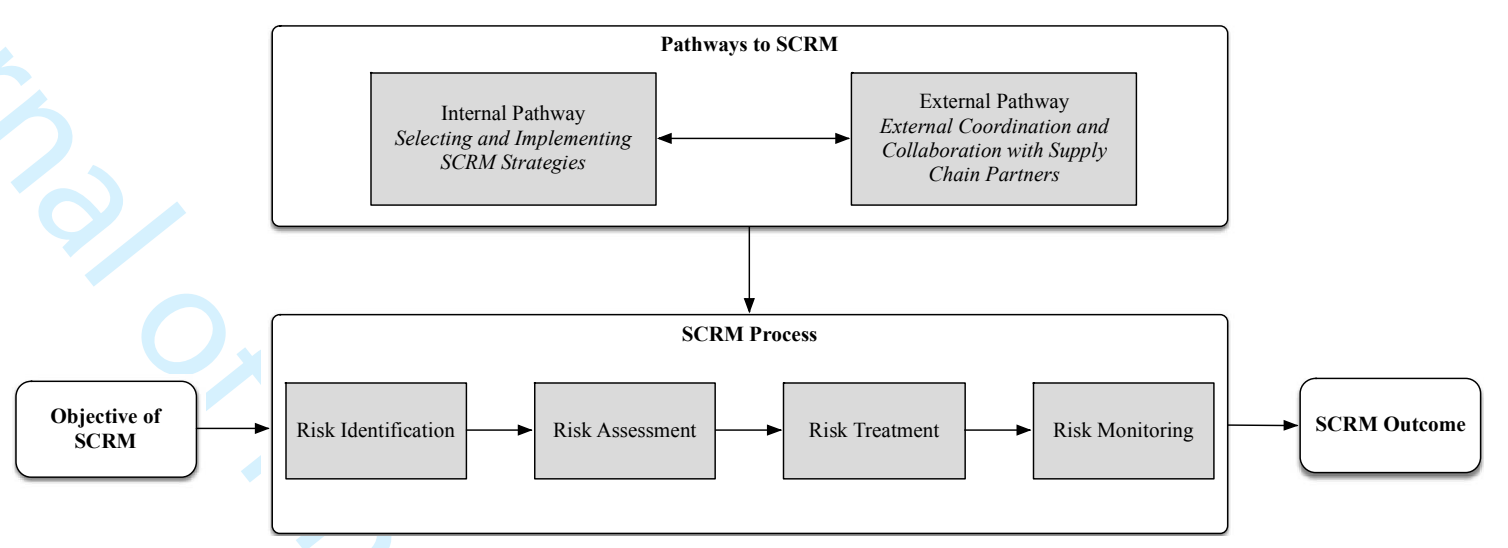

Figure 3: Number of Articles by Year (out of 354 Articles)

60

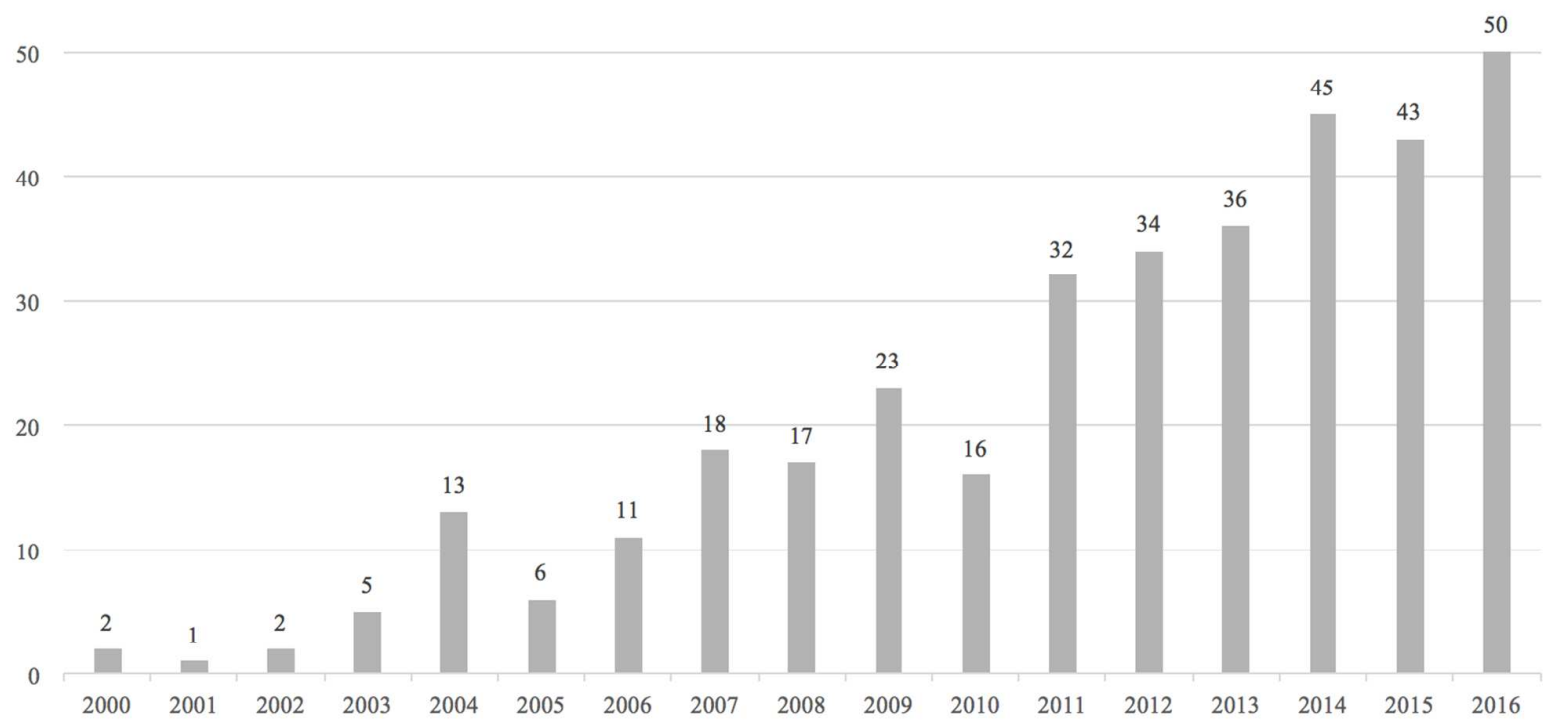


Figure 4: Number of Articles by Journal (out of 354 Articles)

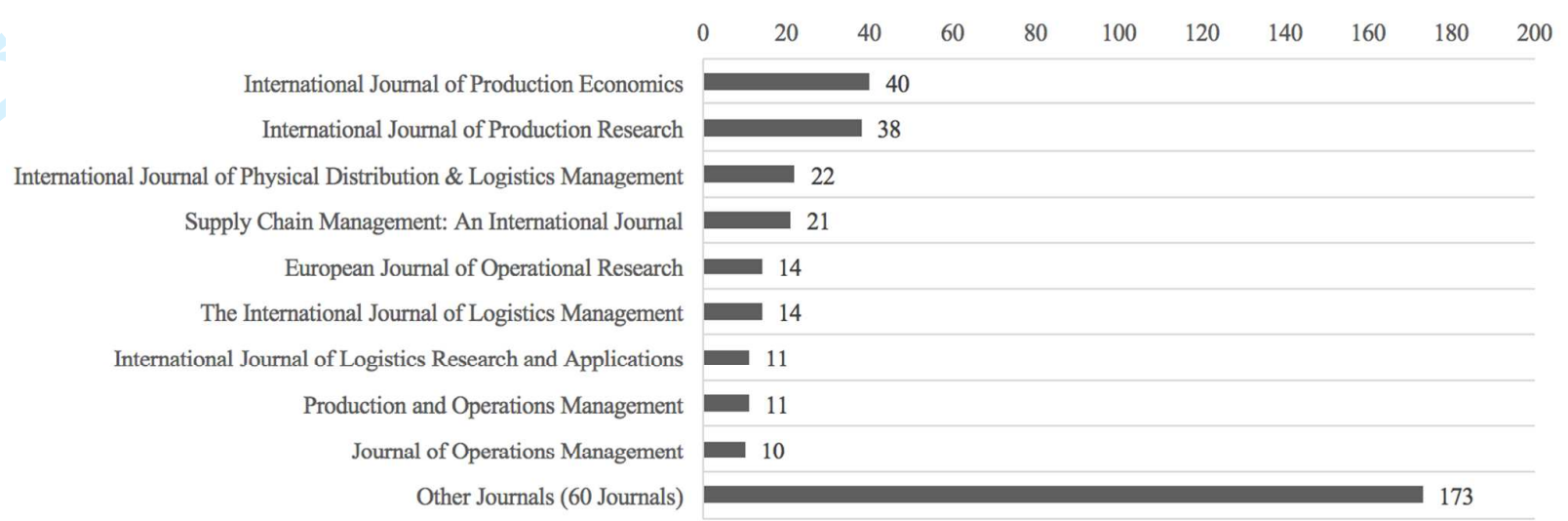

Figure 5: Matrix of Risk Treatment Strategies based on Probability and Impact 